\title{
Are the financial inclusion schemes of India developing the nation sustainably?
}

\author{
Mukul ${ }^{*}$, and Dr Nitin Pathak \\ Chandigarh University, India
}

\begin{abstract}
Introduction- India is the world's largest democracy which has a prominent place in the world. It is proliferating and financial inclusion schemes of government as a piece of evidence for that. However, the development of any nation on the planet should not be at the cost of environmental degradation. There are indeed substantial ties between climate change and sustainable development. Evidence has shown over several decades that global temperatures are on the rise, mainly due to fossil fuel burns. Methodology- For meeting research objectives, a pooled data of variables extracted from the review of literature is constructed. Later by applying PLS-Algorithm on the constructed dataset, conclusions are made. Value- This research will develop insight into whether the financial inclusion scheme of government is sustainably developing the economy or not. Result- There exists a significant relationship between financial inclusion and $\mathrm{CO} 2$ emissions, which concludes that financial inclusion schemes of government are not doing sustainable development. ConclusionThere is an urge to link financial inclusion schemes with sustainable development.
\end{abstract}

\section{Introduction}

India is the second-most populous nation, the seventh biggest by area, and the most populous democracy [1]. In India, $51 \%$ of the pollution is generated by industrial pollutants, $27 \%$ by cars, $17 \%$ by crop burning and $5 \%$ by fireworks. Air pollution causes 2 million Indians to die prematurely each year [2]. It is not plausible to undervalue the purpose of efficient financial inclusion services in promoting money creation and economic growth [3]. An adequate financial infrastructure is required for commercial services such as deposit mobilization, trade facilitation, payment processing provision, and risk management [4]. Financial inclusion extends the reach of financial resources and develops savings amongst the have nots [5]. Financial inclusion is a significant step towards the comprehensive development of the nation[6], [7]. It assists in the overall economic advancement of the impoverished population. In India, efficient financial inclusion must uplift the underprivileged people by equipping them with the transformed financial merchandises and services [8]. There are substantial ties between climate change and sustainable development. Evidence has shown over several decades that global temperatures are on the rise, mainly due to fossil fuel burns

\footnotetext{
${ }^{*}$ Corresponding author: mukulbhatnagar1993@gmail.com
} 
[9]. The emission of carbon into the atmosphere is playing a significant role, and the availability of necessities such as fresh water, food security and energy is projected to impact. Poor and emerging nations will be among those most impacted and unable to deal with projected social, economic and environmental shocks [10].

However, financial inclusion may restrict sustainable development beneath economic globalization and climate change [11]. This research paper attempts to find a piece of statistical evidence that whether financial inclusion is leading to sustainable development or not. It is essential that, as human beings, our economic growth is not leading to environmental degradation. Economic and ecological development should go hand in hand as there is no economy without an environment. This paper will develop an insight into the need to introduce economic reforms, which will lead to sustainable development and economic expansion.

\section{Variables}

Table 1. Variables used in Research.

\begin{tabular}{|l|l|}
\hline VARIABLE & SOURCE \\
\hline Savings & {$[12],[13],[14],[15],[16]$} \\
\hline GDP & {$[5],[17],[18],[19],[20]$} \\
\hline Savings $\rightarrow$ GDP & {$[16],[21],[22],[23]$} \\
\hline GDP $\rightarrow$ Pollution & {$[24],[25],[26]$} \\
\hline
\end{tabular}

\section{Method}

To conclude and meet the research objectives, time-series data of the variables mentioned in table 1 is collected (1991-2019). After collecting data, the significance of the relationship between the variables is analysed with the help of the PLS- Algorithm using Smart PLS software.
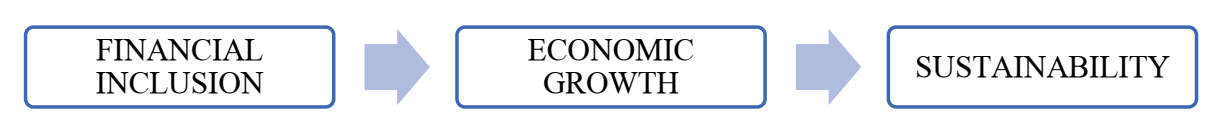

Fig. 1. Conceptual Model.

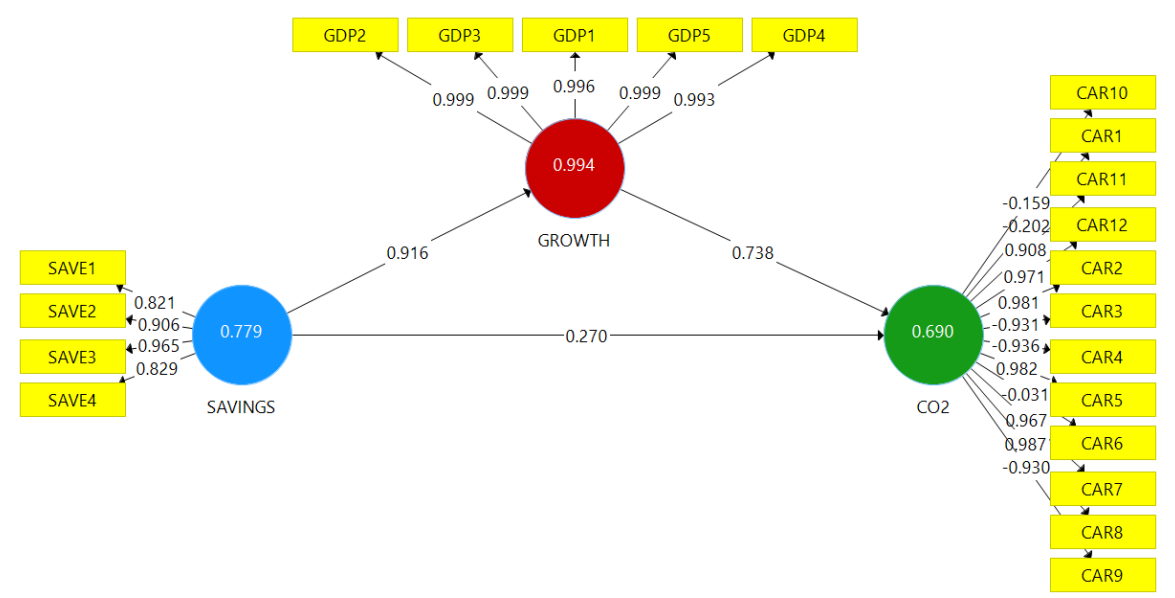

Source: Author's Calculation

Fig. 2. Results of running PLS- Algorithm on conceptual model. 
Table 2. Cross loadings and construct reliability.

\begin{tabular}{|c|c|c|c|c|}
\hline \multicolumn{4}{|c|}{ CROSS LOADINGS } & $\begin{array}{l}\text { Construct } \\
\text { Reliabilit }\end{array}$ \\
\hline PARTICULARS & $\begin{array}{c}\mathrm{CO} 2 \\
\text { Emmissions }\end{array}$ & $\begin{array}{c}\text { GROWT } \\
\mathrm{H}\end{array}$ & $\begin{array}{l}\text { SAVING } \\
\text { S }\end{array}$ & AVE \\
\hline $\begin{array}{l}\text { CO2 emissions (kg per } 2010 \text { US\$ of } \\
\text { GDP) }\end{array}$ & 0.93 & 0.886 & 0.877 & \multirow{12}{*}{0.69} \\
\hline $\begin{array}{l}\text { CO2 emissions (kg per } 2017 \text { PPP \$ of } \\
\text { GDP) }\end{array}$ & 0.931 & 0.887 & 0.876 & \\
\hline $\mathrm{CO} 2$ emissions (kg per PPP \$ of GDP) & 0.936 & 0.87 & 0.90 & \\
\hline $\mathrm{CO} 2$ emissions $(\mathrm{kt})$ & 0.987 & 0.992 & 0.935 & \\
\hline $\mathrm{CO} 2$ emissions (metric tons per capita) & 0.982 & 0.979 & 0.933 & \\
\hline $\begin{array}{l}\mathrm{CO} 2 \text { emissions from gaseous fuel } \\
\text { consumption ( } \% \text { of total) }\end{array}$ & -0.159 & -0.219 & -0.39 & \\
\hline $\begin{array}{l}\mathrm{CO} 2 \text { emissions from gaseous fuel } \\
\text { consumption (kt) }\end{array}$ & 0.908 & 0.89 & 0.918 & \\
\hline $\begin{array}{l}\mathrm{CO} 2 \text { emissions from liquid fuel } \\
\text { consumption ( } \% \text { of total) }\end{array}$ & -0.031 & -0.004 & -0.305 & \\
\hline $\begin{array}{l}\mathrm{CO} 2 \text { emissions from liquid fuel } \\
\text { consumption (kt) }\end{array}$ & 0.967 & 0.981 & 0.853 & \\
\hline $\begin{array}{l}\mathrm{CO} 2 \text { emissions from solid fuel } \\
\text { consumption ( } \% \text { of total) }\end{array}$ & -0.202 & -0.175 & 0.036 & \\
\hline $\begin{array}{l}\mathrm{CO} 2 \text { emissions from solid fuel } \\
\text { consumption (kt) }\end{array}$ & 0.981 & 0.975 & 0.947 & \\
\hline $\begin{array}{l}\mathrm{CO} 2 \text { intensity (kg per kg of oil } \\
\text { equivalent energy use) }\end{array}$ & 0.971 & 0.97 & 0.877 & \\
\hline GDP (constant 2010 US\$) & 0.891 & 0.899 & 0.821 & \multirow{5}{*}{0.994} \\
\hline GDP (constant LCU) & 0.891 & 0.899 & 0.892 & \\
\hline GDP (current US\$) & 0.879 & 0.896 & 0.93 & \\
\hline GDP, PPP (current international \$) & 0.891 & 0.899 & 0.932 & \\
\hline GDP: linked series (current LCU) & 0.862 & 0.893 & 0.864 & \\
\hline Gross savings ( $\%$ of GDP) & 0.629 & 0.631 & 0.821 & \multirow{4}{*}{0.779} \\
\hline Gross savings ( $\%$ of GNI) & 0.638 & 0.641 & 0.829 & \\
\hline Gross savings (current LCU) & 0.874 & 0.867 & 0.906 & \\
\hline Gross savings (current US\$) & 0.864 & 0.868 & 0.965 & \\
\hline
\end{tabular}

Source: Author's Calculation

Table 3. Results of HTMT inference on the variables used in research.

\begin{tabular}{|l|r|r|r|r|}
\hline \multirow{2}{*}{ PARTICULARS } & \multicolumn{4}{|c|}{ HTMTInference } \\
\cline { 2 - 5 } & Original Sample (O) & Sample Mean (M) & $2.50 \%$ & $97.50 \%$ \\
\hline GROWTH -> CO2 Emissions & 0.976 & 0.98 & 0.959 & 1 \\
\hline SAVINGS -> CO2 Emissions & 0.989 & 0.989 & 0.945 & 1.025 \\
\hline SAVINGS -> GROWTH & 0.9 & 0.903 & 0.848 & 0.951 \\
\hline
\end{tabular}

Source: Author's Calculation 


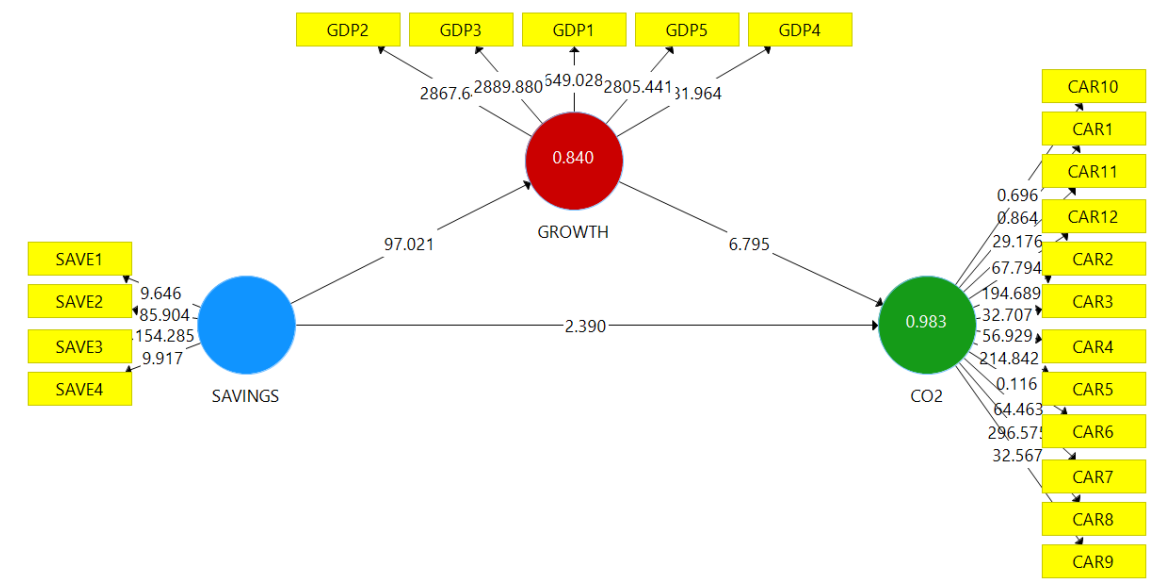

Source: Author's Calculation

Fig. 3. Results of Bootstrapping the Variables used in research.

Table 4. Testing the significance of the relation between variables.

\begin{tabular}{|c|c|c|c|c|c|c|c|}
\hline \multirow{2}{*}{ RELATION } & \multirow{2}{*}{$\begin{array}{c}\text { Original } \\
\text { Sample } \\
(\mathrm{O})\end{array}$} & \multirow{2}{*}{$\begin{array}{c}\text { Sample } \\
\text { Mean } \\
\text { (M) }\end{array}$} & \multirow{2}{*}{$\begin{array}{c}\text { Standard } \\
\text { Deviation } \\
\text { (STDEV) }\end{array}$} & \multirow{2}{*}{$\begin{array}{c}\text { T Statistics } \\
(|\mathrm{O} / \mathrm{STDEV}|)\end{array}$} & \multirow{2}{*}{$\begin{array}{c}\mathrm{P} \\
\text { Values }\end{array}$} & \multicolumn{2}{|c|}{$\begin{array}{l}\text { Confidence } \\
\text { Interval }\end{array}$} \\
\hline & & & & & & $2.50 \%$ & $97.50 \%$ \\
\hline $\begin{array}{l}\text { GROWTH -> } \\
\text { CO2 Emissions }\end{array}$ & 0.738 & 0.732 & 0.112 & 6.561 & 0 & 0.538 & 0.936 \\
\hline $\begin{array}{l}\text { SAVINGS -> } \\
\text { CO2 Emissions }\end{array}$ & 0.27 & 0.274 & 0.117 & 2.313 & 0.021 & 0.058 & 0.474 \\
\hline $\begin{array}{l}\text { SAVINGS -> } \\
\text { GROWTH }\end{array}$ & 0.916 & 0.923 & 0.01 & 93.764 & 0 & 0.909 & 0.947 \\
\hline
\end{tabular}

Source: Author's Calculation

\section{Results and discussion}

\subsection{Cross loadings and AVE}

Table 2 represents the values of cross-loadings and AVE of the variables used in research. From the values derived by performing the calculation on the software smart PLS, it can be observed that the AVE of all the construct is an acceptable limit i.e. more than 0.5 [27], [28].

\subsection{HTMT inference}

By analysing the computations made in Table 3, it can be discerned that mean values lie between the confidence intervals. Hence, the values derived after calculations are acceptable to define the relationship between the variables of the conceptual model.

\subsection{Is Financial inclusion leading to Sustainable development?}

Table 4 tests the significance of the relation between the variables. There is a significant relationship between the variables from the p-values, $t$-values and confidence intervals mentioned in Table 4. Thus, it can be interpreted that financial inclusion leads to growth and growth further, resulting in increasing $\mathrm{CO} 2$ emissions, degrading the environment. 


\section{Conclusion}

Why invest trillions of dollars in finding life on other planets yet spend trillions of dollars to eliminate life on earth? What is wrong with us? One must understand that this is a magnificent planet - not one or two life-forms have been nourished, but millions. The diversity of life in our world, including mammals, birds, plants, insects, worms and bacteria, is striking. Although we have identified several million types of life, more than 10,000 new species are still identified every year. Nevertheless, someplace else, we believe things will be better.

If human life wants to sustain itself on this planet, sustainable development is the only way of development. The present research shows how with an increase in GDP of India, CO2 emissions are also increasing. This has to be stopped as soon as possible. Considering the present situation of the environment, no further delays by the government can be made to link financial advancement with sustainable development.

\section{References}

1. INDIA \& STATES, www.lovemyindia.org

2. Want govt to build 1,600 km green wall along Aravalli, says activist $\mid$ Cities News, The Indian Express (2019) https://indianexpress.com

3. D. Sharma, J. Financ. Econ. Policy, 8(1), 13 (2016)

4. A. Demirgüç-Kunt, L. Klapper, Brookings Pap. Econ. Act., 2013, 279 (SPRING, 2013)

5. E. Dabla-Norris, Y. Ji, R. M. Townsend, D. Filiz Unsal, J. Monet. Econ., 117, 1 (2021)

6. L. Deng, Y. Lv, Y. Liu, Y. Zhao, Risks, 9(5) (2021)

7. V. Balakrishnan, N. L. M. Shuib, Technol. Soc., 65 (2021)

8. J. J. Aduba, Int. J. Soc. Econ. (2021)

9. K. M. Linn, IOP Conference Series: Earth and Environmental Science, 496(1) (2020)

10. V. Gitz, A. Meybeck, L. Lipper, C. Young, S. Braatz, Climate change and food security: Risks and responses (2016)

11. A. Li et al., Environ. Res. Lett., 16(5) (2021)

12. N. Cámara, B. Research, and D. Tuesta, Measuring financial inclusion: a multidimensional index 1 Measuring financial inclusion: a multidimensional index (2017)

13. D. O. Pearce, Financial Inclusion Strategies Reference Framework Financial inclusion strategies (2012) www.worldbank.org

14. K. Feghali, N. Mora, P. Nassif, Q. Rev. Econ. Financ., 80, 236 (2021)

15. R. Shrestha, S. Nursamsu, Financial Inclusion in Asia and Beyond, 227 (Routledge, 2021)

16. R. Chakraborty, R. Abraham, Int. J. Soc. Econ., 48(6), 878 (2021)

17. E. Miklaszewska, New Frontiers in Banking Services: Emerging Needs and Tailored Products for Untapped Markets, 271 (Springer Berlin Heidelberg, 2007)

18. R. Babu, International Journal of Applied Business and Economic Research, 13(5), 3423 (2015)

19. L. O. Uchenna, K. A. Adetiloye, O. Erin, N. J. Modebe, Proceedings of the 28th International Business Information Management Association Conference - Vision 2020: Innovation Management, Development Sustainability, and Competitive Economic Growth, 4384 (2016) 
20. M. O. Al-Smadi, Banks Bank Syst., 13(4), 31 (2018)

21. V. Nagawa, F. Wasswa, E. Bbaale, J. Econ. Struct., 9(1) (2020)

22. T. Petersen, M. Lizarazo López, S. Kaniovski, T. Url, Wirtschaftsdienst, 100(12), 958 (2020)

23. Y. Neog, A. K. Gaur, Indian Growth Dev. Rev., 13(3), 589 (2020)

24. S. Wang, Y. He, M. Song, J. Environ. Manage., 277 (2021)

25. M. N. Sarwar, S. Ali, H. Hussain, J. Clean. Prod., 298 (2021)

26. W.-M. To, P. K. C. Lee, A. K. W. Lau, Sustainability, 13(10), 5545 (2021)

27. J. F. Hair, M. Sarstedt, L. Hopkins, and V. G. Kuppelwieser, Eur. Bus. Rev., 26(2), 106 (2014)

28. M. Sarstedt, The Great Facilitator, 113 (Springer International Publishing, 2019) 